\title{
Assessment of Medical Student's Clinical Reasoning Skills in the Problem Based Learning-Integrated Curriculum
}

\author{
Probleme-Dayalı Öğrenme, Entegre Eğitim Programında Tıp Öğrencilerinin Klinik Akıl Yürütme Becerilerinin \\ Değerlendirilmesi*,**
}

\author{
Meral Demirören ${ }^{1}$, Özden Palaoğlu²
}

1 Ankara Üniversitesi Tıp Fakültesi Tıp Eğitimi ve Bilişsimi Anabilim Dalı. 2 Ankara Üniversitesi Tıp Fakültesi Farmakoloji ve Klinik Farmakolo Anabilim Dal.

Calıșmanın daha önce sunulduğu yerler:

Sözlü bildiri: 1. Eğitim ve Psikolojide Öllcme ve Değerlendirme Kongresi, 14-16 Mayıs 2008, Ankara

** Poster sunumu: V. Ulusal Tip Eğitimi Kongresi, 6-9 Mayıs 2008, izmir Association for Medical Education Congress (AMEE 2008), 30 Ağustos-3 Eylül, Prag.
Received: 04.04.2012 • Accepted: 13.06.2013

\section{Corresponding author}

Uz. Dr. Meral Demirören

Ankara University, Faculty of Medicine, Department of

Medical Education and Informatics

Phone: 0 (312) 5957333

Fax: 0 (312) 3205839

E-mail: demiror@medicine.ankara.edu.tr

Aim: The purpose of the present study is to assess clinical reasoning skills of students at Ankara University School of Medicine. The study was conducted in the 2006-2007 academic year, including 156 Year $3(64 \%)$ students and 98 Year $5(72 \%)$ students.

Materials and methods: Clinical Reasoning Problems (CRPs) developed by Groves et al. (2002) were used. Cronbach Alfa, the reliability coefficient of CRPs was found to be 0.76 .

Results: The total mean score for CRPs of the whole study group was found to be 159,69 \pm 36,19 (maximum 344). It was observed that CRPs total mean scores of Year 5 students were higher than those of Year 3 students $(p<.001)$.

About three fourths of the students generated at least one strong hypothesis for seven out of ten clinical problem (CP). The CPs where the students generated the least strong hypothesis were those with the lowest clinical reasoning performances. The percentage of generating strong hypothesis of Year 5 students was higher than that of Year 3 students $(p<.001)$.

Conclusions: The results obtained from the study showed that experienced learners were better in clinical reasoning performance and generating hypothesis, when compared to novices. These results indicate that CRPs could be used for clinical reasoning assessment in medical education as reliable and valid means.

Key Words: Clinical reasoning, clinical reasoning problems, medical education, problem based learning.

Amaç: Çalıșmanın amacı, Ankara Üniversitesi Tıp Fakültesi'nde öğrencilerin klinik akıl yürütme becerilerini değerlendirmektir. Çalıșma, 2006-2007 akademik yılında 156 Dönem 3 (\%64) ve 98 Dönem 5 (\%72) öğrenci ile yürütülmüștür.

Materyal ve yöntem: Groves ve diğerleri (2002) tarafından geliștirilen klinik akıl yürütme problemleri (CRPs) kullanılmıștır. CRPs güvenirlik katsayısı, Cronbach Alfa, 0.76 bulunmuștur.

Bulgular: Çalıșma grubunun ortalama toplam CRPs puanı 159,69 $\pm 36,19$ (maksimum344) bulunmuștur. Dönem 5 öğrencilerinin ortalama toplam CRPs puanının Dönem 3 öğrencilerinden daha yüksek olduğu $(p<.001)$ gözlenmiștir.

Calıșma grubundaki öğrencilerin yaklașık dörtte üçü, 10 klinik problemden 7'sinde en azından bir güçlü hipotez olușturmuștur. Öğrencilerin en az güçlü hipotez yarattığı klinik problemler, klinik akıl yürütme performanslarının en düșük olduğu klinik problemlerdir. Dönem 5 öğrencilerinin güçlü hipotez yaratma oranı, Dönem 3 öğrencilerinden daha yüksektir $(p<.001)$.

Sonuç: Çalıșmadan elde edilen bulgular, klinik akıl yürütme performansı ve hipotez yaratmada deneyimli öğrencilerin deneyimsiz öğrencilere gore daha iyi olduğunu göstermiștir. Bu bulgular, CRPs'nin tıp eğitiminde klinik akıl yürütmenin değerlendirilmesinde geçerli ve güvenilir șekilde kullabileceğini ortaya koymuștur.

Anahtar Sözcükler: Klinik akıl yürütme, klinik akıl yürütme problemleri, tıp eğitimi, probleme dayalı öğrenme.

It is very well known that one of the most important characteristics of contemporary medical education curricula is the formal and strong emphasis put into clinical reasoning practices (1). It has been suggested that problem based learning $(\mathrm{PBL})$ is able to foster clinical reasoning with the very well known process including a continuous hypothesis generation, testing of the generated hypothesis and eventually validation of 
one of the hypothesis as a diagnosis through an active process where there is continuous information flow. Moreover, clinical reasoning by hypothesis generation and testing has been asserted to be a major necessity because of the complexity of clinical problems, tremendous amount of accessible knowledge and the limited capacity of working memory (2).

The traditional curriculum in Ankara School of Medicine has been restructured by taking into account the contemporary principles of medical education since 2002. Clinical reasoning has been defined as one of the essential competencies to be brought in during the restructured curriculum. Problem based learning is used to foster clinical reasoning in preclinical years in new curriculum.

The present study was undertaken to determine and compare the clinical reasoning skills of students from different levels of the restructured curriculum by using clinical reasoning problems (CRPs).

\section{MATERIAL AND METHODS}

The study has been designed as a crosssectional survey. The dependent variable has been taken as the scores students receive from the CRPs. The independent variable was taken as the level of education.

\section{Study group:}

The study group composed of 245 year3 and 137 year-5 students during 2006-2007 academic year. Year-6 students were excluded as there were no year- 6 student attending the new curriculum. Although it was aimed to reach the whole group, only 150 $(63.7 \%)$ year-3 and 98 (71\%) year-5 students participated in the study.

\section{Clinical reasoning problems}

CRPs were orjinally developed by Groves et al. (3) to evaluate clinical reasoning process, not the accuracy of diagnosis ${ }^{3}$. For each clinical problem (CP) whose clinical accuracy and realistic quality were verified by re- lated specialists, the students were required to determine the two most probable diagnoses and to list the most important clinical features, either positively or negatively related to their diagnosis. The first three stages of clinical reasoning; definition, explication of clinical information and hypothesis generation were aimed to be tested.

CRPs were composed of 10 clinical problems, developed according to systems, pathological processes and patient demographic characteristics to provide content validity. Each $\mathrm{CP}$ was designed to simulate several possible disease conditions (Appendix 1).

After translation into Turkish and pretested on 20 year-4 students, CRPs were applied to a group of nonspecialist medical doctors (residents of Internal Medicine Department) in order to ensure validity of the reference standards to determine the level of clinical reasoning for a given society where the study would take place.

Content validity of CRPs in the study was ensured by domain specialists during both the development of reference standards and the assessment of CRPs. Given the CRPs, the significant statistically difference $(p<0.001)$ between the two groups at different levels of medical education was accepted as an evidence of "structural validity through group differences". The reliability coefficient of CRPs was calculated to be 0.76 , using the Cronbach Alfa method.

Data analysis primarily relied on the comparison of scores obtained from the reference group and the study group. Participation was on a voluntary basis. The study group, year-3 and year- 5 students, were asked to solve the problems personally, without using any reference book.

The written answers of the whole study group ( $\mathrm{n}=254$ ) to the CRPs, consisting of $10 \mathrm{CPs}$ were graded by the principal investigator using the "Assessment and Grading Guide" constructed on the basis of the scores of the reference group. For comparison of each CRP score according to year, t-test was used for independent groups. Mann-Whitney test was used for the cases not normally distributed. Chi-square test was used to determine whether the students who generated strong diagnosis differed according to year.

\section{RESULTS}

Total mean CRP score of the whole study group was found to be 159.69 \pm 36.19 (median: 159.00, minimum and maximum: 62.00/235.00) and showed normal distribution. The maximum score for CRPs was 344 which was $46.4 \%$ of the possible maximum score (Table 1)

Total mean CRP score of year-3 students was found to be $145.0 \pm 31.181$, and $183.0 \pm 31.042$ for year-5 students and the difference was statistically significant $(\mathrm{p}<0.001)$ (Table 2). When scores of each CRP was compared according to years, scores of year-5 students were found to be higher than those of year-3 students: In eight out of $10 \mathrm{CRP}$ (except for 5 and 7), the difference between CRP scores was statistically significant $(\mathrm{p}<0.05)$ (Table 2).

Throughout the study, any diagnosis preferred by more than $50 \%$ of the reference group was considered as "strong diagnosis" and the diagnosis generated by the study group were graded accordingly. In seven CRPs (except for 4, 9 and 10), about the three fourths of the students generated at least one strong diagnose. In Table 3, percentage of strong diagnosis generation according to year is presented. Except for two CPs (1 and 7 ), percentage of strong diagnosis generation by year- 5 students was higher than that of year-3 students and the difference was found to be statistically significant $(\mathrm{p}=0.000)$. 
Table 1: Mean CRP scores for the whole study group

\begin{tabular}{|c|c|c|c|}
\hline CP, No: & Mean score \pm SD & Possible Maximum Score & \% Maximum score \\
\hline $\mathbf{1}$ & $15.29 \pm 5.383$ & 28 & 54.6 \\
\hline $\mathbf{2}$ & $20.84 \pm 6.615$ & 34 & 41.3 \\
\hline $\mathbf{3}$ & $22.18 \pm 8.257$ & 46 & 29.1 \\
\hline $\mathbf{4}$ & $6.12 \pm 3.733$ & 21 & 61.0 \\
\hline $\mathbf{5}$ & $17.09 \pm 4.867$ & 28 & 49.9 \\
\hline $\mathbf{6}$ & $16.97 \pm 5.846$ & 34 & 54.5 \\
\hline $\mathbf{7}$ & $17.98 \pm 6.993$ & 36 & 46.1 \\
\hline $\mathbf{8}$ & $17.04 \pm 8.012$ & 39 & 32.3 \\
\hline $\mathbf{9}$ & $9.70 \pm 6.150$ & 30 & 34.3 \\
\hline $\mathbf{1 0}$ & $16.48 \pm 7.076$ & 48 & 46.4 \\
\hline
\end{tabular}

Table 2: Mean CRPs scores for each cohort

\begin{tabular}{|c|c|c|c|c|c|c|}
\hline \multirow{2}{*}{ CP, No: } & \multirow{2}{*}{$\begin{array}{l}\text { Possible } \\
\text { Maximum } \\
\text { Score }\end{array}$} & \multicolumn{2}{|c|}{ Year $3(n=156)$} & \multicolumn{2}{|c|}{ Year $5(n=98)$} & \multirow[b]{2}{*}{$\mathrm{p}$} \\
\hline & & Mean Score \pm SD & $(\%)^{*}$ & Mean Score \pm SD & $(\%)^{*}$ & \\
\hline 1 & 28 & $14.71 \pm 5.430$ & 52.5 & $16.21 \pm 5.200$ & 57.9 & .014 \\
\hline 2 & 34 & $19.65 \pm 6.691$ & 57.8 & $22.72 \pm 6.061$ & 66.8 & .000 \\
\hline 3 & 46 & $19.22 \pm 7.324$ & 41.8 & $26.90 \pm 7.449$ & 58.5 & .000 \\
\hline 4 & 21 & $5.04 \pm 3.237$ & 24.0 & $7.84 \pm 3.841$ & 37.3 & .000 \\
\hline 5 & 28 & $16.74 \pm 5.070$ & 59.8 & $16.65 \pm 4.495$ & 59.5 & .200 \\
\hline 6 & 34 & $15.73 \pm 5.169$ & 46.3 & $18.95 \pm 6.327$ & 55.7 & .000 \\
\hline 7 & 36 & $18.22 \pm 6.391$ & 50.6 & $17.61 \pm 7.879$ & 48.9 & .523 \\
\hline 8 & 39 & $14.35 \pm 7.525$ & 36.8 & $21.32 \pm 6.844$ & 57.7 & .000 \\
\hline 9 & 30 & $7.26 \pm 5.700$ & 24.2 & $13.58 \pm 4.679$ & 42.3 & .000 \\
\hline 10 & 48 & $14.09 \pm 6.168$ & 29.4 & $20.29 \pm 6.781$ & 42.3 & .000 \\
\hline Total & 344 & $145.0 \pm 31.181$ & 42.2 & $183.0 \pm 31.042$ & 53.2 & .000 \\
\hline
\end{tabular}


Table 3: Percentage of strong diagnosis generation according to cohorts

\begin{tabular}{|c|c|c|c|c|c|c|}
\hline \multirow[t]{2}{*}{ CRP, No: } & \multirow[t]{2}{*}{ Year } & \multicolumn{3}{|c|}{$\begin{array}{l}\text { Strong Diagnosis } \\
\%\end{array}$} & \multirow[t]{2}{*}{$\mathbf{X}^{2}$} & \multirow[t]{2}{*}{$\mathrm{p}$} \\
\hline & & 0 & 1 & 2 & & \\
\hline \multirow{2}{*}{1} & 3 & 7.1 & 73.1 & 19.9 & \multirow{2}{*}{.377} & \multirow{2}{*}{.801} \\
\hline & 5 & 6.1 & 76.5 & 17.3 & & \\
\hline \multirow{2}{*}{2} & 3 & 10.3 & 67.7 & 32.1 & \multirow{2}{*}{43.506} & \multirow{2}{*}{.000} \\
\hline & 5 & 3.1 & 22.4 & 74.5 & & \\
\hline \multirow{2}{*}{3} & 3 & 7.7 & 73.7 & 18.6 & \multirow{2}{*}{73.725} & \multirow{2}{*}{.000} \\
\hline & 5 & 1.0 & 26.5 & 72.4 & & \\
\hline \multirow{2}{*}{4} & 3 & 95.5 & 4.5 & 0.0 & \multirow{2}{*}{52.773} & \multirow{2}{*}{.000} \\
\hline & 5 & 59.2 & 39.8 & 1.0 & & \\
\hline \multirow{2}{*}{5} & 3 & 16.7 & 78.2 & 5.1 & \multirow{2}{*}{75.546} & \multirow{2}{*}{.000} \\
\hline & 5 & 1.0 & 49.0 & 50.0 & & \\
\hline \multirow{2}{*}{6} & 3 & 6.4 & 52.6 & 41.0 & \multirow{2}{*}{15.483} & \multirow{2}{*}{.000} \\
\hline & 5 & 3.1 & 30.6 & 66.3 & & \\
\hline \multirow{2}{*}{7} & 3 & 7.7 & 63.5 & 28.8 & \multirow{2}{*}{1.073} & \multirow{2}{*}{.585} \\
\hline & 5 & 11.2 & 63.3 & 25.5 & & \\
\hline \multirow{2}{*}{8} & 3 & 41.7 & 50.6 & 7.7 & \multirow{2}{*}{64.517} & \multirow{2}{*}{.000} \\
\hline & 5 & 8.2 & 44.9 & 46.9 & & \\
\hline \multirow[t]{2}{*}{9} & 3 & 99.4 & 0.6 & 0.0 & \multirow{2}{*}{185.183} & \multirow{2}{*}{.000} \\
\hline & 5 & 17.3 & 80.6 & 2.0 & & \\
\hline \multirow[b]{2}{*}{10} & 3 & 79.5 & 20.5 & 0.0 & \multirow[b]{2}{*}{53.324} & \multirow[b]{2}{*}{.000} \\
\hline & 5 & 34.7 & 61.2 & 4.1 & & \\
\hline
\end{tabular}

\section{DISCUSSION}

The present study was planned as a cross-sectional design. Crosssectional design which provides data gathering from a larger group in a short time, was preferred since the study was the first to determine development of clinical reasoning in Ankara School of Medicine after curriculum restructuring based on the principles of contemporary medical education. Year-3 and year-5 students were selected as the former represented the end of the preclinical phase and the latter represented the end of the clinical phase of medical education. Although the number of the students participated the study did not limit the statistical methods

used ( $t$ test, nonparametric tests), generalization of the results to the whole population of the study can be taken as a limitation.

The total maximum score percentage of the study group which was found to be $46.4 \%$, is in accordance with those of Groves et al. (3). The statistically significant difference between the total mean scores of year- 3 and year- 5 students supports the fact that clinical reasoning process is not independent of knowledge, and gradually improves by knowledge accumulation and experience (4). From another point of view, this statistical significance can be evaluated as an indicator of the discriminating power of CRPs. When individually compared, year-5 students scored higher than year-3 for eight of the problems. The

most possible explanation of the insignificance between the two cohorts

for the remaining two problems (CP No: $5 \& 7$ ) could be that year 3 students have studied similar cases during their PBL activities. When CPs were ranked based on $\%$ individual scores, three of the CPs (No: 4, 9, 10) for which the student performances were lower, can be defined to be difficult cases. More important was that, difficulty was similar for both cohorts.
Hypothesis generation is very important for clinical reasoning performance. "Strong diagnosis" generation in the present study has been taken as a simulation of hypothesis generation of clinical reasoning. In a study by Allen et al. (5), it was shown that the skill of using and indexing relevant evidence of both medical doctors and students, was a function of early generation of the right hypothesis (5). But, after all, hypothesis/diagnosis generation is a function of previous experience and knowledge (2). In the present study, except for 3 CPs No: $4,9,10)$, the three difficult cases for both of the cohorts, about three fourths of the students have generated at least one strong diagnosis. For the three difficult cases, it can be argued that contribution of hypothetical mistakes to clinical reasoning performance increases depending on the difficulty of the case (1). On the other hand, two CPs (No: $1 \& 7$ ) can be defined as relatively easy problems; no significant difference in strong diagnosis generation was observed 
between the cohorts with over 50\% performance.

Percentage of strong diagnosis generation of year-5 students was significantly higher than that of year-3 students $(p<0.001)$, except for two CPs, is again parallel in line with the finding that experienced learners/physicians generate better hypothesis than novices (6) and gaining experience decreases mistakes in hypothesis generation(1). It has been stated by Nendaz et al. (7) that younger doctors collect less relevant information and diagnose in a less relevant way and doctors have difficulty in relating their knowledge to clinical cases they encounter since they lack either experience in such a case or basic knowledge. They mostly generate a series of possible diagnosis for a given case and they have difficulty in prioritizing such a long list (8).

In medical education, problem based learning during pre-clinical period,

\section{REFERENCES}

1. Groves M, O’Rourke P, Alexander H. Clinical Reasoning: The Relative Contribution of Identification, Interpretation and Hypothesis Errors to Misdiagnosis. Medical Teacher 2003; 25:621-625.

2. Charlin B, Tardif J, Boshuizen HPA. Scripts and medical diagnostic knowledge: Theory and applications for clinical reasoning instruction and research. Academic Medicine 2000; 75: 182-190.

3. Groves M, Scott I, Alexander H. Assesing Clinical Reasoning: A Method to Monitor Its Development in a PBL Curriculum. Medical Teacher 2002; 24:507-515.

4. Newble D, Norman G and van der Vleuten C. Assesing clinical reasoning. In: Higgs J, supports development of clinical reasoning and provides a basis for development of reflective questioning skills and contribution to sample (case) storage (9). Both groups included in the survey have encountered a total of 48 problem-based learning scenarios during the first three years of their medical education, 16 for each year. Except for one CP (No: 4), year-3 students have encountered diseases included in the possible diagnosis categories for all cases in at least one problem based learning scenario. And, the performance of year-3 students to generate at least one strong diagnosis is over $50 \%$ in seven out of ten cases and reaches the performance of year 5 students in two of the cases. These findings support Eshach and Bitterman's (10) suggestions that problem based learning enables students to store information in their mind as substantial index items, defining both patient stories and disease-related rules.

Jones M. eds. Clinical Reasoning in the Health Professions. 2nd ed. Edinburg: Butterworth-Heinemann; 2000. p.156-165.

5. Allen VG, Arocha JF, Patel VL. Evaluating evidence against diagnostic hypotheses in clinical decision making by students, residents and physicians. International Journal of Medical Informatics 1998; 51:91-105.

6. Thomas RE. Problem-based learning: measurable outcomes. Medical Education 1997;

31:320-329.

7. Nendaz MR, Raetzo MA Junod AF, Vu NV. Teaching Diagnostic Skills: Clinical Vignettes or Chief Complaints?, Advances in

\section{CONCLUSION}

Because clinical reasoning is one of the essential competencies of medical education and monitoring and assessing its development has gained great importance.

In the present study, it was shown that CRPs had a discriminating power in clinical reasoning performances of medical students at different levels, thus can be used for the assessment of clinical reasoning, as a reliable and valid method. Clinical cases and reference standards are of critical importance. Comparative studies should be done for reference standards obtained from different groups (nonspecialists, specialists or a mixed group).

The present study was conducted as a cross sectional survey and it is advisable to conduct a longitudinal research to determine every level of improvement throughout medical education.

Health Sciences Education 2000;5:3-10.

8. Bowen JL. Educational strategies to promote Clinical Diagnostic Reasoning. The New England Journal of Medicine 2006; 355:2217-2225.

9. Maudsley G, Strivens EJ. 'Science', 'critical thinking' and 'competence' for Tomorrow's Doctors. A review of terms and concepts. Medical Education 2000; 34:53-60.

10. Eshach H, Bitterman H. From Case-based Reasoning to Problem-based Learning. Academic Medicine 2003; 78:491-496. 


\section{Appendix 1}

\section{CLINICAL PROBLEM}

MA is a 55 year old architect who presents for a check-up. He has noticed that he becomes breathless easily, even after mild exercise. He also mentions that, while he has had a bit of a morning cough for the last few years, it seems to have been more severe and frequent in the last 3 or 4 months. He is also finding that he has to go to the toilet several times during the night.
MA is a regular although infrequent patient of your practice. He does not smoke, and drinks moderately. He has always been a bit overweight, but has lost weight since you last saw him. He has a history of high blood pressure for which he takes captopril. During a period of unemployment 10 years ago, he developed insomnia which still bothers him occasionally. Other medical history includes successful repair of an inguinal hernia when he was 18 and a bout of whooping cough 2 years ago.
On examination, MA's BP is 150/90; his respiratory rate is $20 / \mathrm{min}$ with widespread expiratory wheezing, his heart rate is 90 bpm with a mildly displaced apex beat. You note palmar erythema

1 What do you think is the most likely diagnosis in this patient?

2 Please list the features of the case which you consider support your diagnosis and also those which oppose it, giving an appropriate sign [positive $(+)$ or negative $(-$ )] and weighting to each.

\begin{tabular}{|l|l|l|}
\hline Feature & $\begin{array}{l}\text { Supports (+) } \\
\text { or } \\
\text { Opposes (-) }\end{array}$ & $\begin{array}{l}\text { Weighting } \\
\text { 1: slightly relevant } \\
\text { 2: somewhat relevant } \\
\text { 3: very relevant }\end{array}$ \\
\hline
\end{tabular}

1. What is the most possible diagnosis?

2. List the Case cues positively supporting or negatively countering the possible diagnosis and score them in between 1-3.

\begin{tabular}{|l|l|l|}
\hline Case Cue & $(+)$ supports & Scoring \\
& $(-)$ counters & 1: mildly supports/counters \\
& & 2: moderately supports/counters \\
& & \\
& & \\
\hline & & \\
\hline & & \\
\hline
\end{tabular}

3. What will be your alternative diagnosis if your first possible diagnosis comes out to be wrong?

4. List the Case cues positively supporting or negatively countering this diagnosis and score them in between 1-3.

\begin{tabular}{|l|l|l|}
\hline Case Cue & $(+)$ supports & Scoring \\
& $(-)$ counters & 1: mildly supports/counters \\
& & 2: moderately supports/counters \\
& & \\
& & \\
\hline & & \\
\hline & & \\
\hline & & \\
\hline
\end{tabular}

